\title{
Faith and science dialogue in the Shroud of Turin
}

\author{
JOSEP FERNÁNDEZ-CAPO \\ Doctor en Veterinaria \\ Universitat Autònoma de Barcelona \\ joefzcapo@gmail.com
}

\begin{abstract}
The science of the Shroud of Turin - or sindonology- began with the photograph of this religious relic by Secondo Pia in 1898. In a cultural context where the thesis of the constant conflict between religion and science is still alive, sindonology stands out as a paradigm of the constructive dialogue between faith and science. Independent from the issue of the authenticity of the relic, here is the reflection of such dialogue displaying the mutual services that faith and science render one another. Sindonology also stands out for being a paradigm of interdisciplinary study, which demands the overcoming of knowledge fragmentation.
\end{abstract}

Keywords: Shroud of Turin; Sindonology; Science; Faith; Interdisciplinarity

\section{Introduction}

The science of the Shroud of Turin, also called sindonology, is relatively recent: the photograph of the Shroud by Secondo Pia in 1898 represents the first modern study (Damon et al. 1989, 611). The Shroud is a linen cloth of about $4.4 \mathrm{~m}$ long and $1.1 \mathrm{~m}$ wide, which contains the somatic imprint of the frontal and dorsal images of a crucified man, together with a good number of bloodstains. It first turned up in France (Lirey) in the mid-fourteenth century and is currently venerated as a religious relic in Turin's cathedral. The central sindonological questions are: (1) how was this image imprinted 
on the cloth? and (2) what is the identity of the Man of the Shroud? Both remain unanswered up to this day. Around these two questions, there has arisen an interesting dialogue between faith (theology) and science.

Faith and science have not always lived together peacefully. One may just think of the long and radical confrontation between Creationism and Evolutionism in the United States (Marsden 1983) to see how extreme positions which try to monopolize access to knowledge are of no avail. The idea that faith and science are essentially incompatible so that we must choose between the two is still alive in certain quarters.

Sindonology also lived through an upheaval period in the Academy of Sciences of Paris when science and faith appeared to be incompatible. It will be dealt with later in this work. Suffice it to say for the moment that this conflict was a short-lived and isolated experience. Since then, sindonology has been characterized by both a constructive dialogue between faith and science and interdisciplinarity. This is not a case of a two-side confrontation with respect to the Shroud, with one band of men of faith and fear of science, and another of reductionist scientists who claim to restrict knowledge to what is empirically verifiable. The controversies around the authenticity of the Shroud - whether or not it is a painting (McCrone 1999; STURP 1981), or whether the medieval radiocarbon dating may be considered as definitive (Damon et al. 1989, 615; Rogers 2005, 193) - are the result of healthy scientific debate, which has never tried to hinder the dialogue between faith and science.

It is not the aim of this paper to address the relic's authenticity question with new empirical data or to attempt to explain the image-formation mechanism. We consider the dialogue between faith and science in itself as very interesting regardless of the authenticity of the relic: i.e., of whether the Man of the Shroud turns out to be Jesus of Nazareth or an incredible later standin. As the renowned sindonologist Raymond Rogers once stated, "No matter what the truth is about the Shroud, it is a fascinating study. It can be studied according to the rigorous Scientific Method" (Fanti et al. 2005, Foreword).

To date, the most rigorous and comprehensive study carried out on the Shroud was the Shroud of Turin Research Project (STURP), on 8-13 October 
1978. In 1983, the STURP team member John Heller admitted that "though it was believed that there would be a confrontation between science and religion, none occurred. Rather, the relationship was harmonious and synergistic" (Heller 1983). The present work aims to reflect on the phenomenon of the peaceful and unitary dialogue prevailing between faith and science with respect to the Shroud. This dialogue can be addressed by reflecting on the mutual services that faith and science render one another in this matter.

\section{Services that the science of the Shroud renders to faith}

\subsection{Science stimulates faith}

Science came across the Shroud by chance thanks to the discovery of the negativity of the image (the photograph by Secondo Pia). Subsequently, it was found that the image of the Shroud contained three-dimensional information (Jackson et al. 1984, 2246). These and other findings have turned the relic into a challenge to modern rationality (John Paul II 1998a, n. 2), attracting the interest of millions of people. The Shroud is now a true mass phenomenon (exhibitions of this relic draw big crowds of people and have grown more and more frequent) that challenges both believers and unbelievers. Among sindonologists there are both Roman Catholics (e.g., John Jackson) and Protestants (e.g., Max Frei), Jews (e.g., Barrie M. Schwortz) and agnostics or atheists (e.g., Yves Delage (Rinaldi 1934, 685)). Even the well-known STURP team is made up of members of varying religious beliefs (Marino and Benford 1999).

If it were right that the Image of the Mandylion of Edessa (discovered in 525) and the Shroud of Turin are one and the same, as Ian Wilson claims (Wilson 2010, Introduction), then we would be before a singular piece of fabric that has been preserved and appreciated by all the cultures and religions it has been in contact with: it would have been bought by a pious Jew (Matt. 27:57-59) and hosted by the first Judeo-Christian community of Jerusalem; it would have been venerated in Edessa by the early Christian Church; it would likely have been preserved from destruction thanks to 
the presence of Arab Muslims in Edessa during the iconoclastic struggles (726-787) (Grazia 1998, 145); it would have been revered and guarded by the Greek Christians (Orthodox) in Constantinople from the mid-tenth century to the thirteenth century; it has been venerated and guarded in Europe by the Roman Catholic Church since the fourteenth century (overcoming the threat of attempted arson at least twice: once in Chambéry in 1532 and later in the Guarini Chapel in 1997). Besides, at present it is more and more valued by Protestants worldwide (Dreisbach 2006). All of the above depends on final confirmation of Wilson's hypothesis, an issue still pending, although both liturgical vestiges (Dreisbach 1995) and pollen studies (Frei 1979; Frei 1983; Boi 2012) seem to endorse it. In any case, it seems indisputable that science has led the Shroud to overstep the denominational boundaries of the Christian world: what until Pia's discovery was of exclusively confessional interest (one of the most revered Christian relics: the cloth that presumably wrapped the crucified body of Jesus) has become the most studied piece of cloth in human history (Kearse 2013, 58). The Shroud, thanks to science, is now an object of universal interest.

Before science became interested in the Shroud, many devout people had in fact been attracted by the mysterious image printed on the canvas, an image that, again if Wilson's thesis proved true, would coincide with that other described in Edessa as acheiropoietos: an image not made by human hands. In our time, science has enhanced the attraction of that mysterious image, especially thanks to medical studies in the first half of the last century (Barbet 1953). These provide some interesting information that had been encrypted for centuries, and at the same time show many similarities between the Shroud's information and the New Testament account of the Passion of Christ: the Man of the Shroud was scourged (John 19:1), struck on the head (Mark 15:19), crowned with thorns (John 19:2), crucified (John 19:18), pierced on the side with a sharp object (John 19:34) causing a wound from which there flowed blood and serum (John 19:34), and neither had broken bones (John 19:33) nor experienced putrefaction (Acts $2: 27)$. The science of the Shroud not only does not contradict revelation, but rather seems to confirm it. Due to this uncanny coincidence between 
Shroud and Gospels, the relic of Turin won the title of Mirror of the Gospel (John Paul II 1998a, n. 3).

Additionally, both because of its challenge to modern rationality and amazing coincidence with the Gospels, the Shroud has emerged as an excellent preaching tool (D’Muhala 1996): “the most significant visual aid available to the religious educator for teaching about our Lord's Passion, Death and Resurrection” (Dreisbach 2006). As people today have a great interest in scientific questions, it is easy to talk about Jesus of Nazareth to all sorts of audiences using the Shroud. In a sense, we can say that the science of the Shroud may serve today the mission begun by St. Paul in early Christianity: similarly to how Paul overstepped the denominational barriers of the Jewish world to bring the message of the crucified Jesus to the Gentiles (1 Cor 2:1-2; Gal 1:15-16; Gal 2:7-8), we now see how science enables this relic overstep the boundaries of the Christian world and bring the message of its tortured Man to a non-Christian or neo-pagan world.

There are people (both scientists and non scientists) who have decided to embrace Christianity after learning what science has to say about the Shroud; for instance, the testimony given by Dreisbach (Dreisbach 2006) and the personal testimonies of the sindonologist Ian Wilson (McCowen 2010) and the film producer David Rolfe (Rolfe 2012). For some, the Shroud has become, thanks to science, a sign of credibility: i.e., a motive which makes believing easier because it makes reasonable to believe in a redeeming God (Fossati 1987, 13). These people have gone through an experience similar to that of the Apostle John when he saw the linen cloths lying in the tomb of Jesus: "he saw and believed" (John 20:8). Obviously, if some day science proves the relic is a medieval forgery, then the Shroud will not be a sign of credibility any longer. Here it is only pointed out that in the dialogue between faith and science in the Shroud, science raises or stimulates faith in some observers (not in others). In other words, some people with current data provided by sindonology are inclined to accept the authenticity of the relic and, as a result, they embrace religious faith. For these, it could be applied what Pasteur (1822-1895) used to say: "A little science estranges men from God, but much science leads them back to Him". 
Particularly noteworthy is the role that science is playing in the relationship of Protestants with the Shroud. Since last century, a gradual appreciation of the Shroud has awakened in some Protestant sectors around the world. How has this been possible considering Protestants' natural aversion to relics? The answer is clear: thanks to science. It should be remembered that the Rylands Papyrus (or Papyrus P52) - which contains a piece of text of the Gospel of John 18:31-33.37-38- is generally accepted as the oldest piece of manuscript concerning the figure of Jesus of Nazareth: it was written around the year $125 \mathrm{AD}$. Moreover, according to some Bible scholars, the nearest literary source to the historical facts of the Passion and Resurrection of Jesus is that recorded in 1 Corinthians 15:3-8: scholars generally date Paul's reception of this report only three to eight years after the events in question (Habermas 1999). This is the reason why many Protestants realize that if the authenticity of the relic were confirmed it would become the oldest and nearest historical witness to the facts, as this archaeological artifact is a text that can be read, analyzed and, translated into scientific language (Joseph 2012).

In addition, some Bible scholars believe that if the Shroud were authentic, it would revolutionize research about the historical Jesus and help to unite the Christ of Faith (the one narrated by the Gospels) with the Historical Jesus (product of the exclusive application of the historical-critical method) (Joseph 2012; Scaer 1979, 48-49). From this point of view, one can understand the common (ecumenical) interest of all Christian denominations in the study of the Shroud of Turin as possible hermeneutic evidence about the Gospels.

Both because of the scientific literature and the facts mentioned above, one can see that the Shroud has become a source of various types of dialogue: that between believers and non-believers (faith and science dialogue) (Rinaldi 1934), that among Christians of different denominations (ecumenical dialogue) (Dreisbach 2006), that between Christians and believers of other religions (interreligious dialogue: e.g., between Jews and Christians) (Schwortz 2013), that between Christian missionaries and illiterates (missionary and catechetical dialogue) (Dreisbach 2006), etc. When 
these are analyzed in detail, one can observe that in all of them faith plays a central role mediated by science, as barely existing before Pia's photographic negatives. As it is, science has strengthened faith's role in different areas impinging on the Shroud.

This stimulating influence on faith by the science of the Shroud paradoxically began in a moment of history when it seemed that experimental science - and its practical expression in technology - would definitely draw away man's interest from faith issues. The second half of the nineteenth century and early twentieth century were a golden age for technological civilization (Comellas 2000, 81-109; 2007, 213-227), when humans believed themselves capable of anything thanks to the possibilities afforded by science (e.g., Jules Verne's novels, 1828-1905). It was in that cultural context and, precisely through technology (a photograph), that science entered into dialogue with the relic. According to Dreisbach's opinion, this paradox, which he described as divine irony, still prevails in the neo-positivist XXI century (Dreisbach 2006).

\subsection{Science enriches faith}

Medical and chemical studies on the Shroud show many details not contained in the Gospel narratives: e.g., both the type and position of the nails used for the crucifixion, the shape of the crown of thorns, how the scourging took place; physiognomy and blood type of the Man of the Shroud, etc. (Bucklin 1982; Baima Bollone et al. 1983). For people convinced of the relic's authenticity, the science of the Shroud broadens the knowledge about Jesus of Nazareth supplied by faith (without changing its substance), in addition to confirming it. In this sense, some scholars have called the Shroud The Fifth Gospel (Tamburelli 1982, 3), borrowing St. Jerome’s (342-420) expression about the Holy Land. If the Shroud were a hoax, then it would be an icon (a religious painting) of exceptional originality and strength, no doubt, but would merely remain a very effective illustration of the afflictions described in the Gospel narratives (Kearse 2013, 58).

Pope John Paul II longed for science and faith to be harmonized in the theological enterprise: "Just as Aristotelian philosophy, through the 
ministry of such great scholars as St. Thomas Aquinas, ultimately came to shape some of the most profound expressions of theological doctrine, so can we not hope that the sciences of today, along with all forms of human knowing, may invigorate and inform those parts of the theological enterprise that bear on the relation of nature, humanity and God?” (John Paul II 1988). If the relic were authentic, this yearning would have been partially fulfilled, because thanks to the Shroud today we can speak of Christ's Passion and Death in medical terms (Barbet 1953); and it is possible to put forward hypotheses about the phenomenon of Jesus' resurrection using the language of physics (Jackson 1990, 6-19). Somehow there might occur now in history a third synthesis between faith and reason (reason meaning here experimental science), analogous to those of early Christianity with Greek philosophy and, later on, medieval Christianity with Aristotelianism (Dawson 2007, 183-202; Ratzinger 2004, 162-83). Einstein formulated the advisability of this third alliance with an image: "Science without religion is lame, religion without science is blind" (Einstein 1941); and Pope John Paul II expressed this same idea with another beautiful metaphor: "Faith and reason are like two wings on which the human spirit rises to the contemplation of truth" (John Paul II 1998b, Preamble).

This hypothetical broadening of knowledge about Jesus of Nazareth afforded by sindonology is also having an impact on religious iconography. Regardless of the authenticity of the relic, some artists are using what science has found out about the Shroud as a source of inspiration for their works: e.g., Christ's recent sculptures by Miñarro and by Luigi Mattei (Miñarro 2003; 2004). In this sense, it is well-known that Mel Gibson drew inspiration from the Shroud to recreate the scourging scene in his film "The Passion of the Christ" (Brito 2004, 12-13). According to some scholars, the impact of the Shroud on Christian iconography began in the sixth century (Byzantine icons), when the Mandylion (the alleged Shroud) reappeared in the city of Edessa after a flood (Vignon 1902; Wilson 2010, chap. 10). Later, the Shroud had again an impact on sacred art through the phenomenon of copies (copy paintings of the relic made by artists every time it was exhibited) between the sixteenth and nineteenth centuries (Fossati 
1984, 8-23). The novelty lies now in that the influence of the Shroud on sacred art is mediated by science.

\subsection{Science purifies faith}

There have been said and written many things about the Shroud. Even one can find people who seek to approach the Shroud from an esoteric point of view (e.g., in a comment posted to Katia's Esoteric Christianity Blog on April 2, 2007). In these cases, scientific rigor helps to discard those misinterpretations which would turn the cloth of Turin into a magical object (with hidden powers), showing the lack of rationality that lies behind these fanciful speculations. Sindonology serves faith every time it purifies the relic from esoteric or magical contamination. In the same way that the rationality of Greek philosophy helped to demystify religion in the Greek world (demystification that had occurred previously in the Jewish world, thanks to the sober treatment that the Bible gives the sun and the moon, the great divinities of the pagan world (Ratzinger 2012,106-107)), modern science helps religion not to slide back into myth and magic.

\section{Services that faith renders to the science of the Shroud}

\subsection{Faith stimulates science}

Most sindonological research centers in the world were promoted by people of deep faith: e.g., Cultores Sanctae Sindone (Torino, 1936), American Commission on Studies of the Holy Shroud (New York, 1937), The Holy Shroud Guild (New York, 1951), British Society for the Turin Shroud (London, 1977), Centro Mexicano de Sindonología (Mexico City, 1983), Centro Español de Sindonología (Valencia, 1987), etc. The pioneers of these centers promoted Shroud research driven by the attraction of the Man of the Shroud as possibly identifiable with Christ (D’Muhala 1996). We have already seen that the science of the Shroud can be a stimulus to religious faith; let us address now the question of how faith can also be a stimulus for science.

For some people, following St. Augustine, faith is both a way of knowing and a stimulus to seeking after new knowledge: "crede ut intelligas; 
intellige ut credas" (Augustine of Hippo, Sermon 43, 7 and 9). From this point of view, it is logical for the believer to try to find in nature what he already knows by faith. It could be stated that in the same way that the founders of experimental science (e.g., Copernicus, Galileo and Newton) were led by faith to search for the footprints of the Creator in the Cosmos (Jaki 1978, 49), now many sindonologists are also being driven by faith in their search for the hypothetical footprints of the Redeemer on the Shroud.

In early 1989, the results of the radiocarbon measurements on the Shroud were published: the tests on the samples from the Arizona, Oxford and Zurich laboratories dated the linen of the relic between 1260 and 1390 $\mathrm{AD}$, with at least $95 \%$ confidence. The conclusion was that the linen of the Shroud was medieval (Damon et al. 1989, 615). Later on it has been objected that the single site used for dating the cloth (taken from a wellworn edge) is not representative of the whole sample, but rather contains a repaired, rewoven piece that is chemically distinct from the rest: the original protocol specified a minimum of seven sample sites (spread over the entire Shroud) to be used (Kearse 2013, 57). However, in spite of this objection, the radiocarbon dating results undeniably dampened the hopes of many sindonologists. The disappointment took its toll on some of them. At that juncture, when the challenge posed by the Shroud was threatened, the words of encouragement pronounced by D'Muhala (founding member and president of the STURP) in 1996 (D’Muhala 1996) set the tone for renewed scientific effort. Reading those words one cannot but realize that, apart from other reasons, it was the faith of some sindonologists that kept up research on the Shroud.

Over time it has become clear that the radiocarbon test meant a media blackout for the Shroud, but also triggered a scientific boom. A media blackout first because after being popularized in 1977 by a magnificent documentary ("The Silent Witness" by David Rolfe) and later consecrated in June, 1980, by National Geographic's statement as being "one of the most perplexing enigmas of modern times", the Shroud appeared to have become an artifact with barely any media interest. Nevertheless, paradoxically, the radiocarbon test also triggered an explosion of scientific interest: 
just a quick look at the number of scientific articles listed at the www. shroud.com website is enough to notice that most of them have been written after 1989. The history of sindonology shows that not only research is driven by faith but it is also supported by it in difficult times.

\subsection{Faith respects science}

It is significant that the Roman Catholic Church has not hindered scientific research on its most precious relic (e.g., as shown first in allowing the radiocarbon test in 1986 and afterward in immediately disclosing its results in 1988 before being published in the journal Nature (Crispino 1988, 16)). This fact has not gone unnoticed on the part of Hindus and Buddhists who were surprised by the willingness of Christianity to submit the Shroud to rigorous scientific investigation (Dreisbach 2006). Christian faith is not afraid of science because of its conviction that faith and reason do not contradict each other, as God is the author of both (Tomás de Aquino 1967, 1.VII).

Christian faith relishes the admirable progress of science, because as Lemaittre said, "science is beautiful, deserving to be loved in itself, since it is a reflection of God's creative thinking” (Riaza 2010, 9). Moreover, in the present case, Christianity is completely open as to the verification of this relic and its image's authenticity since nothing of the faith's essence depends on either: this partly explains why the first skeptics about the relic belonged to the clerical intelligentsia of the Roman Catholic Church, specifically, the Bishop Pierre D'Arcis in the fourteenth century, the French historian and bibliographer, Canon Ulysse Chevalier in 1900 and the English Jesuit scholar Herbert Thurston in 1903 (Rodríguez 1998, 46-47; Markwardt 2002). Christian faith is based on Christ's Resurrection -an historical and essential fact for Christians (1 Cor. 15:14-19), as testified by the Gospels-, not the authenticity of the Shroud. Consequently, if the image were a duplicate or science were to demonstrate that the Shroud was a fake all along, belief in the Resurrection would remain intact. Faith would not be shaken (A'Hearn 2011). There simply would not exist a historical artifact supporting it. 
It is also significant that no branch of Christianity has tried to contradict the findings of science on the Shroud: i.e., there has been nothing like the rejection of the Gregorian calendar reform (1582) by non-Catholics (Protestant and Orthodox) (Comellas 2000, 98-99), the condemnation of heliocentrism by an authority of the Roman Catholic Church (Galileo, 1633), or the rejection of evolution theory by the Anglicans (1860) (Brown 2008). It is a matter of faith that Christ was wrapped in a clean linen shroud after his death (Matt. 27:59-60; Mark 15:46; Luke 23:53), but it will never be so that the piece of cloth venerated in Turin is the very same one (Fossati 1987, 13): this is just a scientific question. All that theology might contribute to the science of the Shroud is establishing that a particular piece of evidence does not correspond to revealed truth (e.g., if science claimed the Man of the Shroud is not Jewish) and therefore either the relic is not authentic or the finding should be revised.

From the beginning, the authorities of the Roman Catholic Church have exercised an admirable prudence about not canonizing certain findings that may point to the authenticity of the relic (Scaer 1979, 47). This attitude is consistent with the following recent words from Pope Francis: "believers can not claim that a scientific opinion which is attractive but not sufficiently verified has the same weight as a dogma of faith" (Francis 2013a, n. 243).

The image of the Man of the Shroud had the properties of a photo negative long before photography was invented and developed (in the first half of the nineteenth century). The negativity finding was not made by theology, but by technology and science. It is also clear that theology could not anticipate the findings of science from the knowledge offered by revelation (i.e., the Holy Scriptures and for some Christian denominations also Tradition (Vatican Council II 1965, Dei Verbum n. 8)), since scientific evidence lies outside the theological method: revealed truth is not meant to teach empirical truths, but to show men the way of salvation (Sols 2013, 103). A sound theology recognizes the limits of its own method and respects the autonomy of experimental science.

Some authors who are convinced of the authenticity of the relic have tried to demonstrate the scientific evidence of Jesus' resurrection based 
on the Shroud of Turin (Amalraj 2010). Faith warns us against such claims, knowing that this would mean asking of science something it can not give: there is no laboratory test for divinity (Dreisbach 2006). Christian faith understands that Jesus' risen body went through death to another life beyond time and space: a meta-empirical phenomenon incapable of replication, and therefore not amenable to the method of the natural sciences. For example, the Roman Catholic Church, while recognizing that the existence of God the Creator can be known with certainty by the light of human reason (Catechism of the Catholic Church, n. 36 and n. 286), recognizes that this type of knowledge is different from that of the natural sciences (Catechism of the Catholic Church, n. 31 and n. 284). The same can be said about the resurrection of Christ, a mystery of faith beyond the confines of natural reason. Therefore, although some day the science of the Shroud might give satisfactory answers to all the questions about the formation of the image (how was it made?, when was it done?, who made it?, etc.) and everybody acknowledged it as the true hidden witness of what happened to Jesus of Nazareth twenty centuries ago, this would not increase the historical credibility of the mysterious event of Jesus' resurrection more than the events already narrated in the New Testament, namely, the empty tomb (John 20:11-13, Matt. 28:11-15) and, above all, the numerous appearances of the risen Christ (1 Cor 15: 3-8) (Habermas 1999). The Christian faith cannot require an act of faith based on science, as if it were something scientifically tested. Faith is never imposed by force of scientific proof, otherwise it would cease to be faith and simply become science. Science allows us to get deeper into the sea of the knowledge of earthly nature and map its boundaries, but in order to reach the moon (in our case, the truth of the resurrection of Jesus) other means of transport are required, specifically, faith and theology.

In 1998, during the first centenary of Pia's photograph, Pope John Paul II visited the Shroud and took the opportunity to make some remarks about the attitude of the Roman Catholic Church concerning the science of the Shroud. His words sum up well the content of this section: "since it is not a matter of faith, the Church has no specific competence to pronounce 
on these questions. She entrusts to scientists the task of continuing to investigate, so that satisfactory answers may be found to the questions connected with this Sheet" (John Paul II 1998a, n. 2). All these considerations, besides framing the respect that theology must have for science, are the basis for the climate of intellectual and spiritual freedom which should always encompass the dialogue between faith and science, opening a path of harmony and peace in society (Francis 2013a, n. 242).

\subsection{Faith purifies science}

The nineteenth and twentieth centuries have been described as the centuries of ideologies (Fazio 2006, 149-168). Ideological worldviews tend to conform reality to a set of preconceived ideas, sometimes doing violence to scientific evidence, or even distorting scientific knowledge. Science always needs to be rid of ideology. For example, in Russia quantum mechanics was banned because it was regarded as a bourgeois doctrine and contrary to the dialectical materialism of Marxist philosophy (Sols 2013, 106). Sindonology is not immune against the temptation of ideological manipulation either.

In April 1902, Yves Delage took part in a talk on the authenticity of the Shroud in the Academy of Sciences in Paris. Delage was a world renowned physician and one of the pioneers of sindonology: for more than a year he had studied Pia's photographic negatives, with the help of his colleagues Paul Vignon and Rene Colson. In that lecture, Delage concluded that, according to scientific research, the Man of the Shroud was Christ. This statement angered many of those present, who accused him of betraying the principles of science and free thinking. Delage had to slip out the back door to avoid being assaulted. Marcellin Berthelot, the Secretary of the Academy, censored Delage's presentation paper later published in the Academy's journal: all mentions of Christ were expunged. Delage shortly after wrote: "If our proofs have not been received by certain persons as they deserve to be, it is only because a religious question has been injected into a problem which in itself is purely scientific. If instead of Christ, there was a question of some person such as a Sargon, an Achilles or one of the Pharaohs, no one would have thought of making an objection (...) I have been faithful 
to the true spirit of science in treating this questions, intent only on the truth, not concerned in the least whether the truth affect the interests of any religious party. There are those, however, who have let themselves be swayed by this consideration and have betrayed the scientific method (...) I consider Christ a historical person, and I see no reason why people should be scandalized if there exists a material trace of his existence" (Delage 1902, 685-687; Corsini 2004, 115-117). Then as now, the question of the relic's authenticity is an open issue. However, if some day its authenticity were confirmed, the controversy over Delage would go down in history as a new Galileo case: i.e., the condemnation of a scientific fact by supposing it to be a betrayal of the mainstream thinking canon; however, in this case the sentence would not come from a confessional instance but rather a secular and atheistic one.

The danger of ideological manipulation is also present in some interpretations related to radiocarbon dating. Some have used this to invalidate all the other evidence pointing out to the relic's authenticity. Just because the radiocarbon dating says it is of medieval age that does not mean that one must start to discard everything else: for example, until proven otherwise, both the relationship of the Shroud with the Hungarian Codex Pray (Bongert 1994, 3-4) and the probable link of the Shroud with the Sudarium of Oviedo (Kearse 2013, 59) remain worthy of consideration, being both (the Shroud and the Codex) clearly older than the radiocarbon dating. The link with the Sudarium could be strengthened (or dissolved) in the coming years with the comparative analysis of DNA (both nuclear and mitochondrial) present in blood cells of both tissues (Kearse 2013, 57; 2014). As mitochondrial DNA is inherited strictly from the mother, this test would add the mother factor to the study of the Man of the Shroud, an interesting perspective also from the theological point of view, because as Paul wrote: "But when the time had fully come, God sent forth his Son, born of woman" (Gal 4:4). Mariology (i.e., the Marian perspective of Christian theology) has always considered the Virgin Mary as an icon of the mother woman (mother factor).

On the other hand, even if the radiocarbon dating were correct, the scientific challenge of the Shroud could not be thrown away; it would just 
have been replaced by another question, namely, how could some medieval forger do something that we have not yet the ability to explain or reproduce? (D’Muhala 1996). Therefore, it is understandable that on April 20, 1998, Time Magazine acknowledged the Shroud to be "The Riddle of the Ages" (ten years after the radiocarbon test).

Another ideological biased position is that of those people enthusiastic about the authenticity of the relic that seek to invalidate the results of radiocarbon dating arguing that it is a plot against the Christian faith in Jesus' resurrection. Although the infallibility of the radiocarbon testing is not a dogma, it obviously was made with scientific rigor and its result can only be refuted or complemented by other scientific evidence, still pending, which may fully explain why the radiocarbon test failed. Moreover, radiocarbon dating is consistent with the oldest and undisputed documents related to the actual relic, showing that the Shroud of Turin turned up in Lirey in the mid-fourteenth century (Crispino 1981, 30).

Quite a different approach is that of those sindonologists who think that the radiocarbon results might not conform to reality. In the Shroud history, quite often, what at first seemed to be an obstacle to accepting the authenticity of the relic, was later found to actually contribute to the evidence for its authenticity: e.g., the fact that the Man of the Shroud only shows four fingers on both hands and its subsequent and coherent medical-forensic explanation (if the nail went through the bones of the wrist and hit the median nerve then the thumbs should appear as retracted and hidden under the hand, as they do) (Barbet 1953, 104, 154, and 177); or the bright red color of some bloodstains of the Shroud and its possible relation to high bilirubin levels, characteristic of a man severely beaten before dying (Adler 1986, 57-58). Therefore, the position of those sindonologists is free from ideological contamination, who, without denying the scientific rigor of the radiocarbon test, thinks it might be a new opportunity to strengthen the authenticity of the artifact (D'Muhala 1996).

Aware of the constant danger of the ideological contamination of science, Pope John Paul II urged the scientific community to study the Shroud "without pre-established positions that take for granted results that are 
not such" (John Paul II 1998a, n. 2). These words, pronounced by the then holder of the property of the relic, show that faith can help awaken the critical sense of scientists, broadening the horizons of reason to shed greater light on a world always open to scientific investigation (Francis 2013b, n. 34). Our culture believes that science is independent of both faith and ideology.

If we saw before how science can serve faith freeing it from magic; now we have seen that faith can purify science from the danger of ideology. Faith and science free each other to the extent that they help to mutually recognize and accept their own limits, cleaning and refining each other: "science can purify religion from error and superstition; religion can purify science from idolatry and false absolutes. Each can draw the other into a wider world, a world in which both can flourish” (John Paul II 1988).

\section{Sindonology as a paradigm of interdisciplinary study}

When STURP researchers drafted the conclusions of their work they recognized that "the basic problem from a scientific point of view is that some explanations which might be tenable from a chemical point of view are precluded by physics. Contrariwise, certain physical explanations which may be attractive are completely precluded by the chemistry. For an adequate explanation for the image of the Shroud, one must have an explanation which is scientifically sound, from a physical, chemical, biological and medical viewpoint" (STURP 1981). These words mean that the scientific study of the Shroud demands the unification of knowledge: i.e., it is necessary to overcome the fragmentation of knowledge if we want to get at the truth contained in the Shroud.

In this connection, one marvels at the number of different types of knowledge interested in the study of the relic so far: medicine, botany, biology, history, theology, physics, chemistry, archeology, art, textile technology, philosophy, image technology, numismatics, etc. Note that theology is here one more among many. Therefore, it can be said that sindonology is a paradigm not only of the fruitful coexistence of faith and science, but also 
of interdisciplinary study: i.e., the search for a synthesis between particular and sapiential disciplines toward an in-depth comprehension of reality.

Some thinkers consider that greater prominence should be granted to philosophy (reason in its broadest sense) in the task of coordinating the different types of knowledge (in their particular development, to critically illuminate hasty conclusions and apparent certainties, etc.); in this way the sapiential dimension of knowledge would be recovered (Fossati 1987, 13; John Paul II 1998b, n. 81; Ratzinger and Habermas 2006, 49-68): i.e., that attitude of our forefathers to find a unified and organic vision of knowledge which gave them the ability to search for the ultimate and overarching meaning of life (John Paul II 1998b, n. 81 and n. 85). In this effort to strengthen the leading role of philosophy it would be desirable to recover the metaphysical aspect of the human reason understood as the ability to move from phenomenon to foundation; that is, one should aim at transcending empirical data towards the ultimate origin of reality and get at the question of the roots of being (John Paul II 1998b, n. 83). In other words, and using a biological image, man ought to recover the ability to go from the phenotype (the phenomena) to the genotype (the roots) of reality, thus taking up again the genome project of truth.

Hopefully the reflections of this work may also be of help in guiding the dialogue between faith and science in other current debates, such as "the origin of the universe and creation," "evolution and human dignity," "mind, brain and soul," "artificial intelligence and freedom," "sexual differentiation and the dignity of women," "economic progress and ecological balance," and many others.

\section{Acknowledgements}

Thanks are due to Joseph Ratzinger because his writings are a constant source of inspiration; and to Barrie M. Schwortz whose impressive website allowed me an easy access to the scientific information about the Shroud of Turin. 


\section{References}

Adler, A. 1986. "The origin and nature of blood on the Turin Shroud.” In Turin Shroud - Image of Christ? Proceedings of a Symposium, March 3-9: 57-59. Hong Kong: William Meacham, ed. Accessed January 16, 2015. http://freepages.religions.rootsweb.ancestry.com/ wmeacham/hkconf.htm.

A'Hearn, J. 2011. “What Is the Importance of Science to Faith?” Accessed January 16, 2015. http://www.shroud.com/pdfs/ahearn.pdf.

Amalraj, J. 2010. "Evidence of 'Resurrection of Jesus' in the Shroud of Turin." Accessed January 16, 2015. http://www.shroud.com/pdfs/evidenceAmalraj.pdf. Baima Bollone, P. L., M. Jorio, and A. L. Massaro. 1983. "Identification of the group of the traces of human blood on the Shroud." Shroud Spectrum International 6: 3-6.

Barbet, P. 1953. A Doctor at Calvary: The Passion of Our Lord Jesus Christ As Described by a Surgeon. Editor: P.J. Kenedy.

Boi, M. 2012. "The Ethno-Cultural Significance of the Use of Plants in Ancient Funerary Rituals and its Possible Implications in the Case of Pollen of the Shroud," From the 1st International Congress on the Holy Shroud in Spain, Valencia, April 28-30. Accessed January 16, 2015. http://www.shroud.com/ pdfs/boiveng.pdf.

Bongert, Y. 1994. "The Hungarian Pray Manuscript.” CIELT Revue 55-56: 3-4.

Brito G., A. 2004. "Mel Gibson y La Pasión de Cristo.” Linteum 36: 11-15.

Brown, M. 2008. "Good Religion Needs Good Science.” The Church of England website. Accessed January 16, 2015. http://www.churchofengland.org/our-views/ medical-ethics-health-social-care-policy/darwin/malcolmbrown.aspx.

Bucklin, R. 1982. "The Shroud of Turin: Viewpoint of a Forensic Pathologist." Shroud Spectrum International 5: 3-10.

Comellas, J. L. 2000. El último Cambio de Siglo: Gloria y Crisis de Occidente, 1870-1914. Barcelona: Ariel.

-. 2007. Historia Sencilla de la Ciencia. Madrid: Rialp.

Corsini, M. 2004. Historia de la Sábana Santa. Madrid: Rialp.

Crispino, D. 1981. "Why did Geoffroy de Charny change his mind?” Shroud Spectrum International 1: 28-34.

-. 1988. "The Official Announcement of the Radiocarbon Dating." Shroud Spectrum International 28/29: 16-17.

Damon, P. E., D.J. Donahue, B.H. Gore, A.L. Hatheway, A.J.T. Jull, T.W. Linick, P.J. Sercel, L.J. Toolin, C.R. Bronk, E.T. Hall, R.E.M. Hedges, R. Housley, I.A. Law, C. Perry, G. Bonani, S. Trumbore, W. Woelfli, J.C. Ambers, S.G.E. Bowman, 
M.N. Leese, and M. Tite. 1989. “Radiocarbon Dating of the Shroud of Turin.” Nature 337: 6208: 611-615.

Dawson, C. 2007. Los orígenes de Europa. Madrid: Rialp.

Delage, Y. 1902. “Le Linceul de Turin” Revue Scientifique 22: 683-687.

D’Muhala, T. 1996. “Where do we go from here?” Accessed January 16, 2015. http:// www.shroud.com/dmuhala.htm.

Dreisbach, A. R. 1995. “Liturgical clues to the Shroud's history.” Accessed January 16, 2015. http://www.shroud.com/dreisbch.htm.

-. 2006. "The ecumenical implications of the Shroud of Turin,” The Atlanta International Center for the Continuing Study of the Shroud of Turin, Inc., From the 1st International Shroud Conferences in Terracina and Perugia, Italy, May. Accessed January 16, 2015. http://www.shroud.com/pdfs/dreisbach4.pdf.

Einstein, A. 1941. "Science, Philosophy, and Religion.” A Symposium published by the Conference on Science, Philosophy and Religion in Their Relation to the Democratic Way of Life, Inc., New York.

Fanti, G., B. Schwortz, A. Accetta, J.A. Botella, B.J. Buenaobra, M. Carreira, F. Cheng, F. Crosilla, R. Dinegar, H. Felzmann, B. Haroldsen, P. Iacazio, F. Lattarulo, G. Novelli, J. Marino, A. Malantrucco, P. Maloney, D. Porter, B. Pozzetto, R. Schneider, N. Svensson, T. Wally, A.D. Whanger, and F. Zugibe. 2005. "Evidences for Testing Hypotheses about the Body Image Formation of the Turin Shroud." 3rd International Dallas Conference on the Shroud of Turin, Dallas, Texas, September. Accessed January 16, 2015. http://www.shroud.com/ pdfs/doclist.pdf.

Fazio, M. 2006. Historia de las ideas contemporáneas. Una lectura del proceso de secularización. Madrid: Rialp.

Fossati, L. 1984. “Copies of the Holy Shroud: Part I.” Shroud Spectrum International 12: 7-23.

-. 1987. "Science, Logic, Faith, and the Shroud." Shroud Spectrum International 22: 11-14.

Francis, pope. 2013a. Evangelii Gaudium. Accessed January 16, 2015. http://www. vatican.va/holy_father/francesco/apost_exhortations/documents/papa-francesco_esortazione-ap_20131124_evangelii-gaudium_en.html.

-. 2013b. Lumen Fidei. Accessed January 16, 2015. http://w2.vatican.va/content/ francesco/en/encyclicals/documents/papa-francesco_20130629_enciclica-lumen-fidei.html.

Frei, M. 1979. “Il passato della Sindone alla luce della palinologia.” In: La Sindone e la Scienza, Atti del II Congresso Internazionale di Sindonologia, Torino 1978. Torino: Edizioni Paoline: 191-200. 
-. 1983. "Identificazione e classificazione dei nuovi pollini della Sindone.” In: La Sindone, Scienza e Fede, Atti del II Convegno Nazionale di Sindonologia, Bologna 1981. Bologna: CLUEB: 277-284.

Grazia, M. 1998. La Sábana Santa. El misterio de una impronta de hace dos mil años. Madrid: Promoción Popular Cristiana.

Habermas, G. R. 1999. “Historical Epistemology, Jesus' Resurrection, and the Shroud of Turin," Richmond Conference, Shroud of Turin International Research Conference, Richmond, Virginia, June 18-20. Accessed January 16, 2015. http://www. shroud.com/pdfs/habermas.pdf.

Heller, J. 1983. Report on the Shroud of Turin. Houghton Mifflin Harcourt Publishing Company.

Jackson, J. P. 1990. "Is the Image on the Shroud Due to a Process Heretofore Unknown to Modern Science?" Shroud Spectrum International 34: 3-29.

Jackson, J.P., E.J. Jumper, and W.R. Ercoline, 1984. "Correlation of image intensity on the Turin Shroud with the 3-D structure of a human body shape." Applied Optics, 23 (14): 2244-2270.

Jaki, S. L. 1978. The Road of Science and the Ways to God. University of Chicago Press. John Paul II, pope. 1988. "Letter to reverend George V. Coyne, S.J. director of the Vatican Observatory.” Accessed January 16, 2015. http://www.vatican.va/ holy_father/john_paul_ii/letters/1988/documents/hf_jp-ii_let_19880601_padre-coyne_en.html.

-. 1998a. "Pastoral Visit to Vercelli and Turin (Italy). Address of His Holiness Pope John Paul II.” Accessed January 16, 2015. http://www.vatican.va/holy_father/ john_paul_ii/travels/documents/hf_jp-ii_spe_24051998_sindone_en.html.

-. 1998b. Fides et Ratio. Accessed January 16, 2015. http://www.vatican.va/holy_father/john_paul_ii/encyclicals/documents/hf_jp-ii_enc_15101998_fides-et-ratio_en.html.

Joseph, S.J. 2012. “The Shroud and the 'Historical Jesus'. Challenging the Disciplinary Divide.” Accessed January 16, 2015. http://www.shroud.com/pdfs/sjoseph.pdf.

Kearse, K.P. 2013. "Icons, Science, and Faith: Comparative Examination of the Shroud of Turin and the Sudarium of Oviedo." Theology and Science, 11 (1): 52-61, DOI: 10.1080/14746700.2013.750962.

-. 2014. "DNA Analysis and the Shroud of Turin: Development of a Shroud CODIS." Accessed January 16, 2015. http://www.shroud.com/pdfs/kearse3.pdf.

Marino, J.G., and M.S. Benford, 1999. “The Shroud of Turin: bridge between heaven and earth?” Accessed January 16, 2015. http://www.shroud.com/mrinobnf.pdf. 
Markwardt, J. 2002. “The conspiracy against the Shroud." British Society for the Turin Shroud, Shroud Newsletter 55. Accessed January 16, 2015. http://www. shroud.com/pdfs/n55part3.pdf.

Marsden, G.M. 1983. “Creation versus Evolution: No Middle Way.” Nature 305: 571-574.

McCowen, S. 2010. “Sceptic gives 'resounding yes' to truth of Shroud.” The catholic Weekly, 23 May. Accessed January 16, 2015. http://www.catholicweekly.com. $\mathrm{au} /$ article.php?classID $=3$ \& subclassID=9 \&articleID=6975 \& class=Features \& subclass=A\%20 conversation\%20with.

McCrone, W. 1999. Judgement Day for the Shroud of Turin. Amherst: Prometheus.

Miñarro, J.M. 2003. “El Rostro del Hombre de la Síndone: Memoria del proyecto.” Linteum 35: 4-11.

-. 2004. “El Rostro del Hombre de la Síndone (II): El Rostro Torturado.” Linteum 36: 4-9.

Ratzinger, J. 2004. Truth and Tolerance. Christian Belief and World Religions. San Francisco: Ignatius Press.

-. 2012. La infancia de Jesús. Barcelona: Planeta.

Ratzinger J., and J. Habermas. 2006. Dialéctica de la Secularización. Sobre la razón y la religión. Madrid: Encuentro.

Riaza, E. 2010. La historia del comienzo. Georges Lemaître, padre del Big Bang. Madrid: Encuentro.

Rinaldi, P.M. 1934. "The Holy Shroud.” The Sing 13: 685-688.

Rodríguez A., J.-M. 1998. La Síndone de Turín. Estudios y Aportaciones. Valencia: Centro Español de Sindonología.

Rogers, R.N. 2005. "Studies on the Radiocarbon Sample from the Shroud of Turin." Thermochimica Acta 425: 189-194.

Rolfe, D. 2012. Interview for ReligionenLibertad, 8 Oct. Accessed January 16, 2015. http://www.religionenlibertad.com/articulo.asp?idarticulo=25215.

Scaer, D.P. 1979. “Shroud of Turin: Protestant Opportunity or Embarrassment?” Concordia Theological Quarterly 43: 46-49.

Schwortz, B.M. 2013. "Religious Freedom in Scientific Research.” TEDx Conference, Vatican City, April 19. Accessed January 16, 2015. http://www.shroud.com/pdfs/ tedxtext.pdf.

Sols, I. 2013. “La ciencia lo dijo. Relaciones entre ciencia, razón y fe.” Scientia et Fides 1: 87-149. DOI: http://dx.doi.org/10.12775/SetF.2013.004

STURP (Shroud of Turin Research Project). 1981. “A Summary of STURP’s Conclusions.” Accessed January 16, 2015. http://www.shroud.com/78conclu.htm. 
Tamburelli, G. 1982. "Reading the Shroud, called the Fifth Gospel, with the aid of the computer." Shroud Spectrum International 2: 3-12.

Tomás de Aquino. 1967. Suma contra los Gentiles, Madrid: BAC.

Vatican Council II. 1965. Dogmatic constitution on divine revelation "Dei Verbum," November 18. Accessed January 16, 2015. http://www.vatican.va/archive/ hist_councils/ii_vatican_council/documents/vat-ii_const_19651118_dei-verbum_en.html.

Vignon, P. 1902. Le Saint-Suaire de Turin devant la Science, l'Archeologie, l'Histoire, l'Iconographie, la Logique. Paris: Masson et C. Editeurs.

Wilson, I. 2010. The Shroud. Fresh light on the 2000-Year-Old Mystery... New York: Bantam Books. Kindle edition. 
